\title{
THE ENERGY COST OF SOME INDUSTRIAL OPERATIONS
}

\author{
BY \\ D. TURNER \\ From the Nuffield Department of Occupational Health, Manchester University
}

(RECEIVED FOR PUBLICATION NOVEMBER 29, 1954)

This study forms part of a larger investigation carried out in 1947-48. It aimed at providing a hospital department of cardiology with information regarding the physical effort involved in doing various standard operations. This information was for the use of physicians in advising patients and disablement resettlement officers regarding suitable work. Although the investigation was by no means extensive and the numbers of observations were small, the results appear to be of some value, especially in view of the present interest in the employment of elderly persons.

\section{Method}

Two methods were used for assessing the arduousness of each process. The first was the determination of the metabolic rate of the workers, and the second a subjective assessment, based on a simple " jobanalysis". The subjective assessment was always made before any measurement of the metabolic rate.

Metabolic Determinations.-Several workers on each process were examined. Their metabolic rates were determined during a typical period of the working day by the Douglas-Haldane technique. In preference to the normal type of mouthpiece, a rubber face mask, strapped to a webbing harness worn on the head, was used for collecting the expired air. This had the advantage of preventing any leakage of air by the worker failing to maintain a firm grip on the mouthpiece, and of minimizing the distraction from normal working procedure due to the wearing of respiratory apparatus. The air expired during a known time was collected in a Douglas bag worn on the back, and samples were analysed in the factory by means of a standard Haldane gas analysis apparatus.

The face piece was made by Siebe, Gorman and Co. It was basically of rubber-covered copper, malleable to fit any size or shape of face, with an air cushion round the outer rim to provide an airtight shield. Both inlet and outlet valves were incorporated. The period of acclimatization was at least 10 minutes, and always until breathing was at a normal rate. The apparatus was worn for a further five minutes, or until the Douglas bag was full.
For classification of processes on a metabolic basis, a scale which had been used by Orr and Leitch (1937) was adapted. In its original form that scale classified processes according to the excess metabolism per hour over the resting level in an "average" man of surface area 1.77 sq. m. Converted into terms of total metabolism at work per sq. m. of body surface per hour, the scale becomes :

Light work : Up to 90 calories per sq. m. per hr. Moderate work : 90-134 calories per sq. m. per hr. Heavy work : 135-220 calories per sq. m. per hr.

Very heavy work : Over 220 calories per sq. m. per hr. This was the scale used in the present investigation.

Subjective Assessments. - The investigator made a rough analysis of each process, noting such factors as the time taken for a complete cycle of the operation, the apparent severity of the physical effort involved in the various phases of the workcycle, the amount of walking and lifting necessary, and any other particular sudden stresses. After this analysis the overall severity of the process was assessed and denoted by placing the operation in one of three classes, A, B, or C. Class A contained those jobs which seemed to involve heavy or very heavy work, class B those of moderate severity, while class $\mathrm{C}$ consisted of the light jobs. Each process was then placed in one of three groups within its class. Group 1 denoted that there was considerable variation in the apparent rate of energy expenditure at various times in the cycle, group 3 denoted a relatively steady rate during the whole working time, and group 2 was intermediate.

The analysis notes which were made at the time of observation are not reproduced here. They were rough by comparison with modern time-study methods, and were meant merely as a brief description of a process for the benefit of persons unfamiliar with it. The following is an example, namely the analysis of plate casting.

The operator stands at a mould beside a vat of molten lead. Some moulds are gas-heated. A small scoopful of lead is poured into the mould, then a small quantity of cold water, and the mould is opened. The plate is removed and put aside, the 
mould surfaces sprayed, the mould closed and refilled. The cast plates are stacked away when cool. One cycle of operations takes about half a minute. Working conditions are very warm. Sustained effort is required.

\section{Results}

The investigation was made in three factories (plastics moulding, electric accumulator manufacture, and engineering) and in two Government training centres.

In all, 287 metabolic determinations were made, including 59 on women, and 48 different processes were examined. The results of the experiments are given in Tables 1 to 3, where the metabolic cost and classification are compared with the subjective assessment into a sub-division of class A, B, or C.

Only on rare occasions was more than a single determination of metabolic rate made on one individual. The majority of the observations made on women may be found among the results in Table 3 . Ebonite and plastic finishing, fixing rubber to plates, typing, comptometer operating, and card punching account for most of them. It is difficult to say more than that women were found in the light jobs, since in most cases both men and women were doing the job.

It will be seen from Tables 2 and 3 that there was close agreement between the two systems in the medium and light ranges of work. Of 16 processes arbitrarily assessed as class B, 15 were of medium severity according to the metabolic scale of Orr and
Leitch. The remaining occupation (typewriter mechanic trainee) would have been classified as light work according to the average of the metabolic tests, but of the six tests made on this task the result of one fell within the range of medium work. Table 3 shows that in all the operations classed as "light work" there was complete agreement between the arbitrary judgments and the metabolic classification. With the heavier processes (Table 1) the agreement is not so close, for there was a tendency for the observer to overestimate the severity of this work. The arbitrary judgments were consistent amongst themselves, however, and a correction for this tendency could be applied if necessary.

The frequency distributions show that the individual readings for some processes vary widely. Such variation usually indicates that the operation is not of a routine nature but varies in character from time to time, as, for instance, in a skilled trade such as machine fitting or joinery. This variation may be partly responsible for the discrepancies between the two classifications, as the observer would probably tend to bias his classification in favour of the more strenuous phases of the work. Indeed, when such a classification of operations for use in the placement of unfit persons is made on the basis of metabolic measurements, it would be well to rank operations which show much variation as somewhat more severe than the mean metabolic rate indicates, thus allowing for temporary stress.

TABLE 1

METABOLIC COST OF OPERATIONS RATED AS HEAVY OR VERY HEAVY IN SUBJECTIVE APPRAISAL

\begin{tabular}{|c|c|c|c|c|c|c|c|c|c|c|c|c|c|c|c|c|c|}
\hline \multirow{2}{*}{ Operation } & \multirow{2}{*}{$\begin{array}{c}\text { Arbi- } \\
\text { trary } \\
\text { Classifi- } \\
\text { cation }\end{array}$} & \multirow{2}{*}{$\begin{array}{l}\text { Metabolic } \\
\text { Classifi- } \\
\text { cation }\end{array}$} & \multicolumn{13}{|c|}{$\begin{array}{c}\text { Working Metabolism (Calories per Square Metre } \\
\text { per Hour) }\end{array}$} & \multirow{2}{*}{$\begin{array}{c}\text { Total } \\
\text { No. of } \\
\text { Observa- } \\
\text { tions }\end{array}$} & \multirow{2}{*}{$\begin{array}{l}\text { Mean } \\
\text { Meta- } \\
\text { bolic } \\
\text { Rate }\end{array}$} \\
\hline & & & $\begin{array}{l}90- \\
99\end{array}$ & $\left|\begin{array}{l}100 \\
109\end{array}\right|$ & $\begin{array}{l}110 \\
119\end{array}$ & $\begin{array}{l}120- \\
129\end{array}$ & $\begin{array}{l}130- \\
139\end{array}$ & $\mid \begin{array}{l}140- \\
149\end{array}$ & $\begin{array}{r}* 150 \\
169\end{array}$ & $\left|\begin{array}{l}170- \\
189\end{array}\right|$ & $\left|\begin{array}{l}190- \\
209\end{array}\right|$ & $\begin{array}{r}210- \\
229\end{array}$ & $\left|\begin{array}{l}230- \\
249\end{array}\right|$ & $\left|\begin{array}{c}250- \\
269\end{array}\right|$ & \begin{tabular}{|l|}
$\mid 270-$ \\
289
\end{tabular} & & \\
\hline 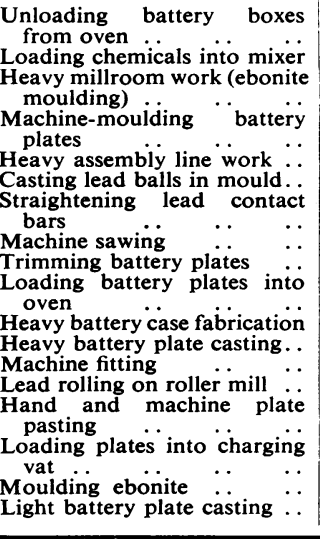 & $\begin{array}{l}\text { A2 } \\
\text { A3 } \\
\text { A3 } \\
\text { A1 } \\
\text { A3 }\end{array}$ & $\begin{array}{l}\begin{array}{l}\text { Very heavy } \\
\text { Heavy }\end{array} \\
\text { Heavy } \\
\text { Heavy } \\
\text { Heavy } \\
\text { Heavy } \\
\text { Heavy } \\
\text { Heavy } \\
\text { Heavy }\end{array}$ & $\frac{-}{4}$ & $\begin{array}{l}\bar{z} \\
= \\
=\end{array}$ & $\begin{array}{l}= \\
\frac{1}{-}\end{array}$ & $\begin{array}{l}\bar{Z} \\
\overline{1} \\
1\end{array}$ & $\begin{array}{l}\frac{1}{-} \\
1 \\
\frac{1}{-}\end{array}$ & $\begin{array}{l}- \\
\frac{1}{-} \\
\frac{-}{1}\end{array}$ & $\begin{array}{l}\frac{1}{2} \\
\frac{1}{1} \\
\frac{2}{-}\end{array}$ & $\begin{array}{l}1 \\
1 \\
1 \\
-1 \\
1 \\
1\end{array}$ & $\begin{array}{l}\frac{1}{1} \\
-\frac{1}{-}\end{array}$ & $\begin{array}{l}- \\
= \\
=\end{array}$ & $\begin{array}{l}2 \\
- \\
= \\
= \\
=\end{array}$ & $\begin{array}{l}= \\
z \\
z\end{array}$ & $\begin{array}{l}- \\
=\end{array}$ & $\begin{array}{r}3 \\
5 \\
3 \\
2 \\
5 \\
4 \\
12 \\
3\end{array}$ & $\begin{array}{l}230 \\
200 \\
190 \\
170 \\
160 \\
160 \\
155 \\
145 \\
150 \\
145 \\
140 \\
140 \\
140 \\
130 \\
130 \\
130 \\
120 \\
120\end{array}$ \\
\hline
\end{tabular}


TABLE 2

METABOLIC COST OF OPERATIONS RATED AS OF MODERATE SEVERITY IN SUBJECTIVE APPRAISAL

\begin{tabular}{|c|c|c|c|c|c|c|c|c|c|c|c|c|c|c|c|c|c|c|c|}
\hline \multirow[b]{2}{*}{ Operation } & \multirow{2}{*}{$\begin{array}{c}\text { Arbi- } \\
\text { trary } \\
\text { Classifi- } \\
\text { cation }\end{array}$} & \multirow{2}{*}{$\begin{array}{c}\text { Meta- } \\
\text { bolic } \\
\text { Classifi- } \\
\text { cation }\end{array}$} & \multicolumn{15}{|c|}{ Working Metabolism (Calories per Square Metre per Hour) } & \multirow{2}{*}{$\begin{array}{c}\text { Total } \\
\text { No. of } \\
\text { Observa- } \\
\text { tions }\end{array}$} & \multirow{2}{*}{$\begin{array}{c}\text { Mean } \\
\text { Meta- } \\
\text { bolic } \\
\text { Rate }\end{array}$} \\
\hline & & & $\left|\begin{array}{c}50 \\
59\end{array}\right|$ & $60-$ & 70 & $80-$ & $90-$ & $\begin{array}{l}100 \\
109\end{array}$ & $-\begin{array}{l}110 \\
119\end{array}$ & $\begin{array}{l}120 \\
129\end{array}$ & $\begin{array}{r}130 \\
139\end{array}$ & $\begin{array}{l}140 \\
149\end{array}$ & $\begin{array}{c}* 150 \\
169\end{array}$ & $\begin{array}{r}170 \\
189\end{array}$ & $\begin{array}{r}190- \\
209\end{array}$ & $\begin{array}{l}210- \\
229\end{array}$ & $\begin{array}{l}230 \\
249\end{array}$ & & \\
\hline 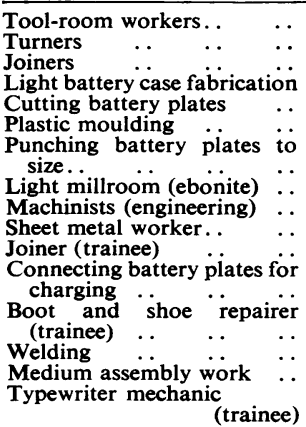 & $\begin{array}{l}\text { B2 } \\
\text { B2 } \\
\text { B2 } \\
\text { B2 } \\
\text { B2 } \\
\text { B2 } \\
\text { B2 } \\
\text { B1 } \\
\text { B3 } \\
\text { B3 }\end{array}$ & $\begin{array}{l}\text { Moderate } \\
\text { Moderate } \\
\text { Moderate } \\
\text { Moderate } \\
\text { Moderate } \\
\text { Moderate } \\
\text { Moderate } \\
\text { Moderate } \\
\text { Moderate } \\
\text { Light }\end{array}$ & $\begin{array}{l}- \\
- \\
Z \\
-\end{array}$ & $\begin{array}{l}Z \\
Z \\
Z \\
-\end{array}$ & $\begin{array}{l}\overline{1} \\
- \\
= \\
- \\
\frac{2}{-}\end{array}$ & $\begin{array}{l}\frac{-}{3} \\
\frac{1}{2} \\
-2 \\
2 \\
1\end{array}$ & $\frac{-}{\frac{2}{3}}$ & $\begin{array}{c}- \\
3 \\
1 \\
3\end{array}$ & $\begin{array}{l}2 \\
1 \\
1 \\
2 \\
1 \\
1 \\
2 \\
-\end{array}$ & $\frac{1}{\frac{2}{2}}$ & $\begin{array}{l}\frac{-2}{1} \\
1 \\
1 \\
1 \\
1 \\
- \\
- \\
- \\
- \\
-\end{array}$ & $\frac{\overline{1}}{\overline{\frac{1}{2}}}$ & $\begin{array}{l}\overline{1} \\
\frac{1}{-} \\
\overline{-} \\
\overline{-} \\
-\end{array}$ & $\begin{array}{l}\frac{1}{1} \\
= \\
- \\
= \\
=\end{array}$ & $\begin{array}{l}E \\
E \\
-\end{array}$ & $\begin{array}{l}= \\
= \\
= \\
= \\
= \\
=\end{array}$ & $\begin{array}{l}\overline{1} \\
\overline{-}\end{array}$ & $\begin{array}{r}4 \\
4 \\
18 \\
5 \\
14 \\
9 \\
5 \\
5 \\
5 \\
12 \\
8 \\
8 \\
3\end{array}$ & $\begin{array}{l}130 \\
125 \\
120 \\
115 \\
110 \\
110\end{array}$ \\
\hline
\end{tabular}

TABLE 3

METABOLIC COST OF OPERATIONS RATED AS LIGHT IN SUBJECTIVE APPRAISAL

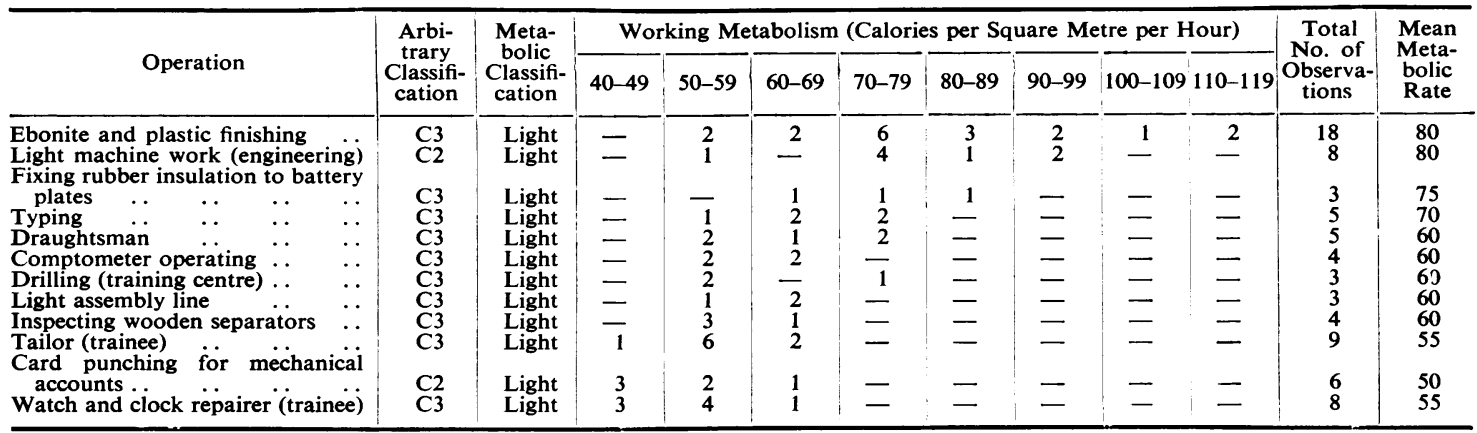

The chief function of the arbitrary grouping, in conjunction with an overall assessment of effort, is to indicate whether a process demands the use of energy at a steady rate or whether the work is done in bursts interspersed with rest pauses. There does not appear to be any simple method of checking the accuracy of this grouping.

The results of this investigation indicate that an observer can classify occupations with a fair degree of accuracy after a little experience without making any physical measurements. Thus a single observer could rapidly survey the processes in local industry and compile an index of classifications and analytical notes of sufficient accuracy to be of help to medical officers when they are suggesting suitable employment for the unfit.

\section{Summary}

Assessments of the severity of the work involved in 48 industrial processes are reported. The assess- ments were made on two bases : (1) measurements of the metabolic rate during work, and (2) subjective appraisal by an observer. Close agreement between the two methods of assessment suggests that for the placement of unfit or elderly workers satisfactory results can be obtained without recourse to metabolic measurements. A single observer could rapidly survey processes in local industry and compile an index of suitable occupations which should be of value to medical officers.

I wish to express my indebtedness to Professor R. E. Lane for the facilities to carry out this study and for his unfailing interest and encouragement, to Professor W. Schlapp for much guidance, and the loan of the necessary physiological apparatus, and to the many persons in industry without whose willing cooperation the results could not have been obtained.

\section{REFERENCE}

Orr ,J. B., and Leitch, I. (1937). Nutr. Abstr. Rev., 7, 509 